ISSN 1896-8147

DOI: http://dx.doi.org/10.21784/EiZ.2016.009

\title{
Opłata od posiadania psów na przykładzie gmin województwa kujawsko-pomorskiego ${ }^{1}$
}

\author{
Fee for dog ownership on the example \\ of Kujawsko-Pomorskie municipalities
}

\begin{abstract}
Streszczenie:
Artykuł poświęcony został omówieniu specyficznej daniny publicznej obowiązującej w polskim systemie podatkowym, jaką był kiedyś podatek, a dziś już opłata od posiadania psów. W publikacji w sposób kompleksowy omówiono konstrukcję prawną opłaty zgodnie $\mathrm{z}$ regulacjami zawartymi w ustawie z dnia 12 stycznia 1991 r. o podatkach i opłatach lokalnych oraz przedstawiono wyniki badań empirycznych przeprowadzonych drogą elektroniczną w gminach województwa kujawsko-pomorskiego, które posiadają na swoim obszarze omawianą opłatę. Celem badania było ustalenie, czy

1 Niniejszy artykuł powstał na bazie badań i pracy magisterskiej Magdaleny Jurczuk pt. „Opłata od posiadania psów w gminach województwa kujawskopomorskiego".
\end{abstract}


opłata od posiadania psów w tych gminach generuje koszty, dochody, czy też osiągnięte dochody wystarczają tylko na pokrycie kosztów związanych z poborem tej opłaty. Autorka badania dążyła do odpowiedzi na pytanie, czy ta danina publiczna pełni typową funkcję fiskalną, czy też jej występowanie ma podłoże o charakterze wychowawczym bądź kompensacyjno -odszkodowawczym. Artykuł powstał w oparciu o analizę aktów prawnych, dostępnej literatury przedmiotu oraz przy wykorzystaniu orzecznictwa sądów administracyjnych. Ponadto przedstawiono wyniki badań empirycznych, które stanowiły istotną część pracy magisterskiej Magdaleny Jurczuk o takim samym tytule jak poniższy artykuł.

Abstract: The article is about the specific public levy that existed in the Polish tax system as a tax. Nowadays it is the fee for dog ownership. The publication is about legal fees in accordance to the regulations on local taxes and fees contained in the Act of 12 January 1991 and presents the results of empirical research conducted electronically in the municipalities of Kujawsko-Pomorskie, which have discussed fee on their area. The aim of the study was to determine whether the charge of having dogs in these municipalities generate costs, revenues, or income achieved sufficient only to cover costs associated with the collection of the fee. The author of the study has sought to answer the question whether this public tribute functions as a typical fiscal fee or its occurrence is based on educational or compensating role. This article is based on the analysis of legal acts, the available literature and using case law of administrative courts. Moreover, the authors presented the empirical research taken from Ms Magdalena Jurczuk thesis titled as this article.

Słowa kluczowe: opłaty lokalne; opłata od posiadania psów; opodatkowanie psów

Keywords: local fees; the fee for dog ownership; dogs taxation 


\section{Wprowadzenie}

Polski system podatkowy, obecnie bardzo rozbudowany, przewiduje wprowadzenie w drodze uchwały na terenie danej gminy zadziwiającej i dość nietypowej daniny publicznej, jaką był kiedyś podatek, a dziś już opłata od posiadania psów. Historia podatku od posiadania psów w Polsce jest bardzo bogata. Wraz z kolejną nowelizacją ustawy regulującej podatki i opłaty lokalne zmieniała się konstrukcja tego podatku, katalog zwolnień podatkowych oraz charakter jego wprowadzenia - obligatoryjny lub fakultatywny.

Przełomowym momentem w historii tej daniny było jej zniesienie jako podatku z dniem 1 stycznia 2008 r. Dokonano tego na podstawie ustawy z dnia 7 grudnia 2006 r. o zmianie ustawy o podatkach i opłatach lokalnych oraz zmianie niektórych innych ustaw². Istotnym jest, że ustawodawca nie zrezygnował wtedy całkowicie z funkcjonowania omawianej daniny publicznej, natomiast przekształcił ją w opłatę o charakterze fakultatywnym, która uregulowana została w art. 18a ustawy z dnia 12 stycznia 1991 r. o podatkach i opłatach lokalnych ${ }^{3}$. Powodem takiego a nie innego działania ustawodawcy był fakt masowej krytyki funkcjonowania podatku od posiadania psów, zarówno przez obywateli będących jego podatnikami, jak i samorządy gmin, które zobowiązane były do pobierania i egzekwowania należności z jego tytułu. Podatnicy często na przedmiot opodatkowanie reagowali śmiechem spowodowanym niedowierzaniem, że opodatkowaniu podlega posiadanie psów. Zasadniczym argumentem, który nieustannie podnoszono przez obie strony, był fakt, że wpływy z omawianej daniny publicznej nie były znaczące, a wręcz marginalne. Kwestia niezadowolenia społecznego w tym czasie była na tak wysokim poziomie, że konieczność zmian w tej dziedzinie była niezbędna4

Dz.U. z 2006 r., Nr 249, poz. 1828.

Tekst jedn.: Dz.U. z 2016 r., poz. 716 ze zm., dalej: „ustawa” lub u.p.o.l.

4 J. Politowicz, Funkcje i efektywność opłaty od posiadania psów, [w:] Studenckie Prace Prawnicze, Administratywistyczne i Ekonomiczne 15, Wrocław 2014, s. 111. 
Charakterystycznym dla opłaty jest stwierdzenie, że to danina publiczna, która posiada wszystkie cechy podatku (tj. przymusowość, bezzwrotność, jednostronność ustalania, przewłaszczenie, świadczenie pieniężne) poza jedną: opłata, w przeciwieństwie do nieodpłatnego podatku, jest daniną odpłatną5. Oznacza to, że w zamian za świadczenie pieniężne wnoszący je podmiot otrzymuje od związku publicznoprawnego, na rzecz którego opłata jest wnoszona, świadczenie wzajemne, zazwyczaj w postaci usługi (np. po uregulowaniu opłaty skarbowej usług w postaci otrzymania stosownego zaświadczenia), którego wartość odpowiada wartości świadczenia pieniężnego ${ }^{6}$.

Współcześnie obowiązująca opłata od posiadania psów posiada wszystkie cechy podatku, gdyż jest świadczeniem charakteryzującym się brakiem cechy odpłatności, która w doktrynie uważana jest za najistotniejszy element konstrukcyjny opłat ${ }^{7}$. Analiza katalogu opłat lokalnych zawartych w ustawie o podatkach i opłatach lokalnych pozwala na zasadne stwierdzenie, że niektóre świadczenia, mimo iż posiadają wszystkie cechy podatku, nazywane są przez ustawodawcę opłatami. Z tego względu nasuwa się pytanie: z jakich względów daniny spełniające wszystkie cechy podatków i w istocie rzeczy będące podatkami ustawodawca w przepisach prawnych określa opłatami?8

\section{Konstrukcja prawna opłaty od posiadania psów}

Zgodnie z umocowaniem zawartym w art. 18a ust. 1 u.p.o.l. „Rada gminy może wprowadzić opłatę od posiadania psów. Opłatę pobiera

5 B. Brzeziński, Wprowadzenie do prawa podatkowego, Toruń 2008, s. 29.

6 Z. Ofiarski, Ogólne prawo podatkowe. Zagadnienia materialnoprawne i proceduralne, Warszawa 2010, s. 25.

7 K. Lasiński-Sulecki, W. Morawski, Komentarz do art. 18 a ustawy o podatkach i opłatach lokalnych, [w:] T. Brzezicki, K. Lasiński-Sulecki, W. Morawski, J. Wantoch-Rekowski, Ustawa o podatkach i opłatach lokalnych. Komentarz, Gdańsk 2013, s. 480 .

8 L. Etel, R. Dowgier, Podatki i opłaty lokalne - czas na zmiany, Białystok 2013, s. 96. 
się od osób fizycznych posiadających psy". W ten sposób z dniem 1 stycznia 2008 r. katalog opłat lokalnych został poszerzony o dodatkową fakultatywną daninę publiczną, która może - lecz nie musi - być wprowadzona na terenie danej gminy w formie stosownej uchwały ${ }^{9}$. Ustawodawca w tym przepisie wyraźnie wskazuje, że podmiotem, na którym ciąży obowiązek podatkowy, pod warunkiem jego ustanowienia, z tytułu opłaty od posiadania psów, jest osoba fizyczna posiadająca minimum jednego psa.

Natomiast w sytuacji, gdy pies jest własnością osoby prawnej lub jednostki organizacyjnej nieposiadającej osobowości prawnej, obowiązek zapłaty opłaty nie powstanie ${ }^{10}$. Warto zwrócić uwagę na wyrok Naczelnego Sądu Administracyjnego z dnia 20 sierpnia 2002 r11, zgodnie z którym w sytuacji „kiedy pies stanowi majątek spółki cywilnej, wspólnik tej spółki pozbawiony jest nad nim takiego władztwa, które uzasadniałoby jego obowiązek podatkowy". Istotnym jest, że przytoczony wyrok zapadł na podstawie nieobowiązujących już przepisów prawa, natomiast nadal zachowuje swoją aktualność w literaturze przedmiotu. Zaznaczyć należy, że spółka, nie mając podmiotowości prawnej, nie może być właścicielem psa, co w rezultacie sprowadza się do faktu, że posiadaczami są jej wspólnicy, którzy powinni być podatnikami. W takim przypadku nie wiadomo również, czy odpowiedzialność za zobowiązanie podatkowe ciąży solidarnie na wszystkich wspólnikach, czy też może być rozbite na poszczególne jednostki. Ze względu na pewnego rodzaju ułomność regulacji uznaje się, że opłata ta nie może być nałożona na wspólników spółki, a tym bardziej na samą spółkę 12 .

9 D. Michta, L. Pankrac, Podatki i opłaty lokalne. Komentarz. Orzecznictwo, Warszawa 2015, s. 118.

10 K. Lasiński-Sulecki, W. Morawski, Komentarz do art. 18 a ustawy o podatkach i opłatach..., s. 481.

11 III SA 3153/01, Centralna Baza Orzeczeń Sądów Administracyjnych (CBOSA)

12 K. Lasiński-Sulecki, W. Morawski, Komentarz do art. 18 a ustawy o podatkach $i$ opłatach..., s. 481. 
Przedmiotem opodatkowania jest posiadanie psa na terenie danej gminy. Natomiast problem rodzi się w sytuacji, gdy osoba fizyczna odda go $\mathrm{w}$ posiadanie zależne, które uregulowane jest $\mathrm{w}$ art. 336 ustawy z dnia 23 kwietnia 1964 r. - Kodeks cywilny ${ }^{13}$. Zgodnie z art. 337 Kodeksu cywilnego posiadacz samoistny nie traci posiadania $\mathrm{w}$ sytuacji, gdy odda drugiemu rzecz w posiadanie zależne. Nie jest wtedy jasne, na kim ciąży obowiązek podatkowy w zakresie opłaty od posiadania psów, gdyż w takiej sytuacji zauważane są dwa podmioty, które teoretycznie mogłyby być podatnikami.

Kolejnym elementem konstrukcyjnym opłaty od posiadania psów jest jej stawka podatkowa określana jako instrument, który służy do określenia kwoty należności podatkowej w stosunku do podstawy opodatkowania ${ }^{14}$. Samorządowe organy stanowiące gminy decydują o wysokości opłat lokalnych, stosując ograniczenia przyjęte przez ustawodawcę w art. 19 u.p.o.l., z tym że podejmując uchwałę w sprawie określania stawek, nie mogą przekraczać górnych granic określonych w ustawie. W myśl art. 19 pkt 1 lit. f) ustawy stawka opłaty od posiadania psów nie może przekroczyć 100 zł rocznie od jednego psa, jednakże trzeba zaznaczyć, że co roku obowiązująca stawka ulega zmianie.

Zgodnie $\mathrm{z}$ art. 20 ust. 1 ustawy górne granice stawek kwotowych określonych w art. 19 pkt 1 i obowiązujących w danym roku podatkowym ulegają corocznej zmianie na następny rok podatkowy w stosunku odpowiadającym wskaźnikowi cen towarów i usług konsumpcyjnych w okresie pierwszego półrocza roku, w którym stawki ulegają zmianie, w stosunku do analogicznego okresu roku poprzedniego ${ }^{15}$. Górne granice stawek kwotowych podatków i opłat lokalnych ogłaszane są w drodze obwieszczenia ministra właściwego do spraw fi-

13 Tekst jedn.: Dz.U. z 2015 r. poz. 1844 ze zm.

14 C. Kosikowski, J. Matuszewski, Opodatkowanie posiadania psów czyli płacz ze śmiechu wokół budy, Warszawa 2002, s. 234.

15 Wskaźnik cen ustalany jest na podstawie komunikatu Prezesa Głównego Urzędu Statystycznego ogłoszonego w Dzienniku Urzędowym Rzeczypospolitej Polskiej „Monitor Polski” w terminie 20 dni po upływie pierwszego półrocza. 
nansów publicznych, które publikuje się w Dzienniku Urzędowym Rzeczypospolitej Polskiej „Monitor Polski”. Poniższa tabela wskazuje górne granice stawki kwotowej opłaty od posiadania psów w latach 2008-2016.

Tabela 1. Maksymalne stawki opłaty od posiadania psów w latach 2008-2016.

\begin{tabular}{|c|c|c|}
\hline Lp. & Rok & Stawka opłaty w złotych \\
\hline 1. & 2008 & 100 \\
\hline 2. & 2009 & $104,20^{16}$ \\
\hline 3. & 2010 & $110,65^{17}$ \\
\hline 4. & 2011 & $115,31^{19}$ \\
\hline 5. & 2012 & $119,93^{20}$ \\
\hline 6. & 2013 & $121,01^{21}$ \\
\hline 7. & 2014 & $121,50^{22}$ \\
\hline 8. & 2015 & $120,05^{23}$ \\
\hline 9. & 2016 & \\
\hline
\end{tabular}

Źródło: Opracowanie własne na podstawie obwieszczeń ministra właściwego do spraw finansów publicznych.

16 Obwieszczenie Ministra Finansów z dnia 29 lipca 2008 r. w sprawie górnych granic stawek kwotowych podatków i opłat lokalnych w 2009 r. (M.P. Nr 59, poz. 531).

17 Obwieszczenie Ministra Finansów z dnia 3 sierpnia 2009 r. w sprawie górnych granic stawek kwotowych podatków i opłat lokalnych w 2010 r. (M.P. Nr 52, poz. 742).

18 Obwieszczenie Ministra Finansów z dnia 30 lipca 2010 r. w sprawie górnych granic stawek kwotowych podatków i opłat lokalnych w 2011 r. (M.P. Nr 55, poz. 755).

19 Obwieszczenie Ministra Finansów z dnia 19 października 2011 r. w sprawie górnych granic stawek kwotowych podatków i opłat lokalnych w 2012 r. (M.P. Nr 95, poz. 961).

20 Obwieszczenie Ministra Finansów z dnia 2 sierpnia 2012 r. w sprawie górnych granic stawek kwotowych podatków i opłat lokalnych w 2013 r. (M.P. , poz. 587).

21 Obwieszczenie Ministra Finansów z dnia 7 sierpnia 2013 r. w sprawie górnych granic stawek kwotowych podatków i opłat lokalnych w 2014 r. (M.P. 2013, poz. 724).

22 Obwieszczenie Ministra Finansów z dnia 7 sierpnia 2014 r. w sprawie górnych granic stawek kwotowych podatków i opłat lokalnych w 2015 r., (M.P., poz. 718).

23 Obwieszczenie Ministra Finansów z dnia 5 sierpnia 2015 r. w sprawie górnych granic stawek kwotowych podatków i opłat lokalnych w 2016 r. (M.P., poz. 735). 
Zobowiązanie podatkowe w opłacie od posiadania psów, mimo braku określonych przepisów ustawowych, powstaje z mocy prawa (pod warunkiem ustanowienia tej opłaty w drodze uchwały), zatem należność winna być uregulowana bez wezwania obowiązanego do jej zapłaty przez organ podatkowy. Ustawodawca nie przewidział w odniesieniu do posiadaczy psów żadnych obowiązków związanych ze składaniem deklaracji, co oznacza, że posiadacze psów zobowiązani są jedynie do samodzielnego obliczenia kwoty opłaty i wpłacenia go we właściwym terminie na rachunek gminy. Należy zauważyć, że stawka roczna opłaty, zasady jej ustalania, poboru oraz termin płatności muszą wynikać z podjętej w tym zakresie uchwały rady gminy. W przypadku nieuiszczenia należności podatkowej w terminie organ podatkowy ma prawo wszcząć postępowanie zmierzające do określenia wysokości zobowiązania podatkowego i wydania w tym zakresie decyzji na podstawie art. $21 \S 3$ Ordynacji Podatkowej24 o charakterze deklaratoryjnym, co oznacza, że wynikającą z niej należność podatnik musi uiścić wraz z odsetkami za zwłokę naliczonymi jak dla zaległości podatkowej25.

Szczegóły dotyczące zasady poboru oraz terminy płatności opłaty od posiadania psów, jak już wcześniej wspomniano, powinna zawierać uchwała, którą zobowiązana jest podjąć rada gminy. Wobec tego, że ustawa milczy w tej materii, słuszne jest, aby samorządowe organy stanowiące gminy skrupulatnie określiły zasady dotyczące poboru omawianej daniny publicznej i terminów jej zapłaty. Głównym tego celem jest uniknięcie ewentualnych luk oraz wątpliwości w przyszłym stosowaniu uchwały. Opłata od posiadania psów jest daniną roczną, toteż powinna być pobierana raz w roku od jednego psa ${ }^{26}$.

Ze względu na fakt, że obowiązek podatkowy zapłaty daniny publicznej ciążący na konkretnej osobie może ustać w trakcie trwania

24 Tekst jedn. Dz.U. z 2017 r., poz. 201 ze zm.

25 R. Dowgier, L. Etel, B. Pahl, M. Popławski, Podatki i opłaty lokalne. 601 pytań i odpowiedzi, Warszawa 2012, s. 660.

26 A. Ciąglewicz-Miśta, N. Ciąglewicz, A. Talik, Podatki i opłaty lokalne. Komentarz. Projekty uchwał. Orzecznictwo, Warszawa 2011, s. 69. 
roku podatkowego, za logiczne uważa się przyjęcie zasady proporcjonalności zmniejszenia opłaty. Oczywistym jest, że zachodzi to w sytuacji utraty psa ${ }^{27}$. Analogicznie przyjmując, nabycie psa w trakcie roku podatkowego skutkować może współmiernym pomniejszeniem opłaty do okresu, w którym zwierzę faktycznie się pojawiło. Należy zaznaczyć, że przedstawione rozwiązanie nie jest obligatoryjne, natomiast rada gminy ma pełne prawo do jego wykorzystania ${ }^{28}$.

Jak stanowi art. 19 pkt 2 u.p.o.l., rada gminy w odniesieniu do opłat objętych ustawą ma prawo do:

1. zarządzania poboru daniny publicznej w drodze inkasa,

2. wskazania wybranych inkasentów,

3. określenia wysokości wynagrodzenia inkasentów.

Jak trafnie uznał NSA w wyroku z dnia 21 września 2007 roku$^{29}$, „status inkasenta zobowiązanego do poboru podatków i opłat stanowiących dochód budżetu jednostek samorządu terytorialnego powinien wynikać wprost z aktu prawa miejscowego, jakim jest stosowna uchwała rady gminy wydana na podstawie upoważnienia ustawowego". Zarządzenie poboru omawianej daniny publicznej w drodze inkasa nie jest równoznaczne $\mathrm{z}$ określeniem wynagrodzenia za inkaso w sytuacji, gdy w uchwale rady gminy nie ma stosownej wzmianki na ten temat ${ }^{30}$. Potwierdzeniem powyższych słów jest orzeczenie WSA w Opolu z dnia 14 lipca 2009 roku31, w którym czytamy, że „brzmienie art. 19 pkt 2 u.p.o.l. nie przewiduje obligatoryjności ustalenia wynagrodzenia inkasenta w sytuacji, gdy zarządzono pobór opłat lokalnych w drodze inkasa”. Ponadto sąd wskazał, że „rada gminy może ustalać wynagrodzenie dla inkasentów z tytułu poboru podatków stanowiących dochody, odpowiednio budżetu gminy, powiatu lub

27 D. Michta, L. Pankrac, Podatki i opłaty lokalne..., s. 119.

28 A. Ciąglewicz-Miśta, N. Ciąglewicz, A. Talik, Podatki i opłaty lokalne. Komentarz..., S. 70.

29 II FSK 1008/06, CBOSA.

30 P. Borszowski, Ustawa o podatkach i opłatach lokalnych. Komentarz, Warszawa 2011, s. 249.

31 I SA/Op 277/09, CBOSA. 
województwa. Brzmienie powyższego zapisu nie budzi zatem żadnych wątpliwości, że skoro rada gminy może ustalać wynagrodzenie inkasentów, to mamy do czynienia z uprawnieniem fakultatywnym a nie obligatoryjnym".

Kolejną kwestią do omówienia jest katalog sytuacji, w których nie pobiera się opłaty od posiadania psów. Wyłączenia, jakie oferuje nam prawodawca, prezentowane są $\mathrm{w}$ art. 18a ust. 2 ustawy. Zatem obligatoryjnemu zwolnieniu z uiszczania opłaty podlegają:

1. członkowie personelu przedstawicielstw dyplomatycznych, urzędów konsularnych oraz inne osoby zrównane z nimi na podstawie ustaw, umów bądź zwyczajów międzynarodowych, jeżeli nie są obywatelami polskimi i nie mają stałego miejsca pobytu na terytorium Rzeczypospolitej Polskiej - pod warunkiem wzajemności. Omawiany przepis jest konsekwencją prawną międzynarodowych regulacji ${ }^{22}$;

2. osoby zaliczane do znacznego stopnia niepełnosprawności w rozumieniu przepisów ustawy z dnia 27 sierpnia 1997 r. o rehabilitacji zawodowej i społecznej oraz zatrudnianiu osób niepełnosprawnych $^{33}$, a wyłączenie dotyczy posiadania tylko jednego psa;

3. osoby niepełnosprawne $\mathrm{z}$ tytułu posiadania psa asystującego. Zgodnie z wyżej wskazaną ustawą są to osoby, których niepełnosprawność została potwierdzona jednym z odpowiednich orzeczeń:

a) zakwalifikowaniu przez organy orzekające do jednego z trzech stopni niepełnosprawności,

b) całkowitej lub częściowej niezdolności do pracy,

c) niepełnosprawności, wydanym przed ukończeniem 16 roku życia.

W tym przypadku ustawodawca postanawia wyłączyć spod opodatkowania psa asystującego, którego należy pojmować jako psa właściwie wyszkolonego oraz specjalnie oznaczonego, który może być

32 P. Borszowski, Ustawa o podatkach i opłatach lokalnych. Komentarz..., s. 243.

33 Tekst jedn. Dz.U. z 2010 r., Nr 214, poz. 1407 ze zm. 
przewodnikiem osoby niewidomej, niedowidzącej, a także psa asystenta osoby niepełnosprawnej ruchowo, który pomaga w życiu społecznym ${ }^{34}$;

4. osoby w wieku powyżej 65 lat prowadzące samodzielnie gospodarstwo domowe, ale tylko z tytułu posiadania jednego psa. W tym przypadku ustawodawca przyjął dwa kryteria, tj. wiek oraz fakt samodzielnego prowadzenia gospodarstwa domowego. W związku z tym, że nie zostało określone w przepisach jego pojęcie, zawsze niezbędna jest każdorazowa weryfikacja indywidualnych przypadków ${ }^{35}$;

5. podatnicy podatku rolnego od gospodarstw rolnych z tytułu posiadania nie więcej niż dwóch psów. W tej regulacji istotne jest, czy dany podmiot mieści się $\mathrm{w}$ definicji podatnika $\mathrm{w}$ ustawie $\mathrm{z}$ dnia 15 listopada 1984 roku o podatku rolnym ${ }^{36}$

\section{Opłata od posiadania psów w gminach województwa kujawsko-pomorskiego}

Przedmiotem przeprowadzonego badania empirycznego było zbadanie funkcjonowania opłaty od posiadania psów w gminach oraz miastach województwa kujawsko-pomorskiego, które zdecydowały się na podjęcie stosownej uchwały w sprawie jej wprowadzenia na swoim terenie. Podstawowym celem badania było ustalenie, czy opłata od posiadania psów w tych gminach generuje koszty, dochody, czy też osiągnięte dochody wystarczają tylko na pokrycie kosztów związanych z poborem tej opłaty. Badanie miało na celu ustalenie, czy ta danina publiczna pełni typową funkcję fiskalną, czy też jej występowanie ma podłoże o charakterze wychowawczym bądź kompensacyjno-odszkodowawczym. Zrealizowane badanie miało odpowiedzieć na

\footnotetext{
P. Borszowski, Ustawa o podatkach i opłatach lokalnych. Komentarz..., s. 244-246.

Tamże, s. 246.

66 Tekst jedn. Dz.U. z 2016r., poz. 617.
} 
pytanie, czy opłata od posiadania psów jest w ogóle opłacalna z punktu widzenia organów samorządu terytorialnego.

Terenem przeprowadzonego badania było województwo kujawsko - pomorskie, które powstało z dniem 1 stycznia 1999 roku na mocy ustawy z dnia 24 lipca 1998 roku o wprowadzeniu zasadniczego trójstopniowego podziału terytorialnego państwa ${ }^{37}$. Województwo kujawsko-pomorskie składa się z 19 powiatów oraz 4 miast na prawach powiatu (tj. Bydgoszcz, Toruń, Włocławek, Grudziądz). Administracyjnie województwo to podzielone jest na 144 gminy (wiejskie 92, miejskie - 17, wiejsko-miejskie - 35).

Po przeanalizowaniu Biuletynów Informacji Publicznej poszczególnych gmin i miast województwa kujawsko-pomorskiego ustalono, iż spośród wszystkich jednostek samorządu terytorialnego najniższego szczebla zaledwie $44 \mathrm{z}$ nich posiadają na swoim obszarze fakultatywną opłatę od posiadania psów ${ }^{38}$, co stanowi $30,55 \%$ ogółu województwa. Do tych gmin w dniu 6 kwietnia 2016 roku wystosowano drogą elektroniczną wiadomość z prośbą o wypełnienie kwestionariusza ankiety dotyczącej opłaty od posiadania psów.

Przed rozpoczęciem badania autorka wyróżniła kilka podstawowych problemów badawczych dotyczących funkcjonowania opłaty od posiadania psów w gminach województwa kujawsko-pomorskiego.

37 Dz.U. z 1998 r., Nr 96, poz. 603.

38 Opłatę od posiadania psów posiadają następujące gminy: w powiecie świeckim gmina Nowe i Osie; w powiecie grudziądzkim - gmina Łasin; w powiecie sępoleńskim - gminy: Kamień Krajeński, Sępólno Krajeńskie, Więcbork, Sośno; w powiecie bydgoskim - gmina Koronowo, Osielsko i Nowa Wieś Wielka; w powiecie chełmińskim - gmina Chełmno; w powiecie brodnickim - gmina Brzozie i Zbiczno; w powiecie nakielskim - gmina Mroczno i Nakło nad Notecią; w powiecie toruńskim - miasto Chełmża i gmina Chełmża; w powiecie golubsko-dobrzyńskim miasto Golub-Dobrzyń; w powiecie rypińskim - miasto Rypin i gmina Rypin; w powiecie żnińskim - gminy: Barcin, Żnin i Gąsawa; w powiecie inowrocławskim - miasto Inowrocław; w powiecie aleksandrowskim - miasto Ciechocinek oraz gminy: Aleksandrów Kujawski i Zakrzewo; w powiecie lipnowskim - gminy: Dobrzyń nad Wisłą, Skępe i Tłuchowo; w powiecie mogileńskim - gmina Mogilno, Strzelno i Dąbrowa; w powiecie radziejowskim - miasto Radziejów oraz gminy: Osięciny i Topólka; w powiecie włocławskim - miasta: Lubraniec i Włocławek oraz gminy: Chodecz, Lubień Kujawski, Boniewo, Choceń, Fabianki, Włocławek. 
Po przeprowadzonym badaniu chciała znaleźć odpowiedzi na poniższe pytania:

1. Od kiedy $\mathrm{w}$ badanych gminach obowiązuje opłata od posiadania psów?

2. Jaką podstawową funkcję pełni w gminach i miastach województwa kujawsko-pomorskiego opłata od posiadania psów?

3. Czy generuje ona dochody, koszty lub jedynie takie dochody, które pozwalają na pokrycie kosztów związanych z jej poborem?

4. Ile osób zobowiązanych do uiszczenia opłaty zapłaciło tę należność w 2015 roku?

5. Czy nieuiszczenie opłaty skutkuje wszczęciem postępowania podatkowego wobec podatnika?

6. Czy gminy i miasta województwa kujawsko-pomorskiego planują rezygnację z opłaty od posiadania psów na swoim terenie?

Kolejnym etapem procedury badawczej było określenie hipotez roboczych, które w literaturze przez M. Łobockiego nazywane są „próbą odpowiedzi na sformułowane uprzednio problemy badawcze, przy czym są one świadomie przyjętymi przez badacza przypuszczeniami, wymagającymi potwierdzenia bądź odrzucenia $\mathrm{w}$ wyniku przeprowadzonych badań"39. Zgodnie z przyjętymi wyżej problemami badawczymi sformułowano kilka hipotez roboczych, które zostały zweryfikowane w trakcie badania empirycznego:

1. W większości gmin i miast województwa kujawsko-pomorskiego opłata od posiadania psów obowiązuje z chwilą wejścia w życie przepisów ją wprowadzających.

2. W badanych gminach i miastach dominują pozafiskalne funkcje opłaty.

3. W niektórych gminach dochody pozwalają jedynie na pokrycie kosztów związanych z jej poborem, a w nielicznych funkcjonowanie opłaty generuje koszty zamiast dochodów.

39 M. Łobocki, Wprowadzenie do metodologii badań pedagogicznych, Kraków 2007, s. 132. 
4. Większość osób zobowiązanych do regulowania świadczenia pieniężnego uiszcza opłatę we wskazanym terminie.

5. Nieuiszczenie opłaty przez osoby zobowiązane skutkuje we wszystkich gminach wszczęciem odpowiedniej procedury postępowania podatkowego.

6. Gminy oraz miasta województwa kujawsko-pomorskiego nie planują rezygnacji z opłaty od posiadania psów.

Metodą badawczą wykorzystaną w badaniu empirycznym była metoda wywiadu socjologicznego, techniką - ankieta, a narzędziem służącym do zbierania niezbędnych informacji - kwestionariusz ankiety. Ankieta zawierająca 8 pytań (w tym 1 pytanie otwarte i 7 pytań zamkniętych) w dniu 6 kwietnia 2016 r. drogą elektroniczną została wysłana do wszystkich jednostek, w których wcześniej ustalono obowiązywanie opłaty od posiadania psów (44 jednostki samorządowe). $\mathrm{Z}$ uwagi na fakt, iż zgodnie $\mathrm{z}$ obowiązującymi przepisami prawa ${ }^{40}$ „udostępnienie informacji publicznej na wniosek zainteresowanego następuje nie później niż w terminie 14 dni od dnia złożenia wniosku", badanie zakończono w dniu 20 kwietnia 2016 r. Do tego czasu wpłynęło zaledwie 20 ankiet, które zakwalifikowane zostały do ostatecznej analizy, którą przedstawiono poniżej.

W badaniu ankietowym dotyczącym opłaty od posiadania psów wzięło udział 20 gmin/miast województwa kujawsko-pomorskiego spośród wszystkich 44, w których obowiązuje opłata od posiadania psów, co stanowi ponad $45 \%$ ankietowanych. Pytanie pierwsze dotyczyło liczby mieszkańców w danej gminie lub mieście. Zdecydowaną większość - 85\% (17 jednostek) stanowiły tereny zamieszkiwane przez niewielką liczbę osób, szacowaną na poniżej 20 tysięcy mieszkańców. Pozostałą część - 15\% (3 jednostki) stanowili respondenci, na których terenie zamieszkuje od 20 do 100 tysięcy mieszkańców.

Pytanie drugie dotyczyło określenia dokładnego roku, w którym gmina/miasto zdecydowało się na wprowadzenie fakultatywnej opła-

40 Art. 13 ust. 1 ustawy z 6 września 2001 r. o dostępie do informacji publicznej (tekst jedn. Dz.U. z 2015r., poz. 2058 ze zm.). 
ty od posiadania psów. W tym pytaniu $100 \%$ ankietowanych wskazało, że przedmiotowa opłata we wszystkich gminach zaczęła obowiązywać od 2008 r., czyli z momentem jej wprowadzenia przez przepisy ustawy o podatkach i opłatach lokalnych. Tym samym potwierdziła się pierwsza z hipotez roboczych postawiona przed rozpoczęciem badania.

Kolejne pytanie związane było z określeniem funkcji, jaką spełnia opłata od posiadania psów w ankietowanych gminach/miastach. Połowa ankietowanych - 50\% wskazała, że ta danina publiczna spełnia na ich terenie funkcję fiskalną. 30\% ankietowanych zaznaczyło, że opłata od posiadania psów pełni funkcję wychowawczą, a $20 \%$ uczestników badania postawiło na funkcję kompensacyjnoodszkodowawczą. Wyniki badań nie potwierdziły założenia badacza o dominującym wpływie pozafiskalnych funkcji opłaty od posiadania psów, gdyż funkcja fiskalna jest tak samo ważna, jak dwie pozostałe, zaliczane do funkcji pozafiskalnych. Spowodowało to sytuację, w której nie można stwierdzić jednoznacznie, która funkcja ma charakter przewodni. W rezultacie można dojść do wniosku, że każda z badanych gmin/miast województwa kujawsko-pomorskiego, wprowadzając na swój teren opłatę od posiadania psów, kieruje się przede wszystkim indywidualnością swoich potrzeb.

Następne pytania poświęcono kwestiom finansowym, a mianowicie temu, czy opłata od posiadania psów generuje w poszczególnych jednostkach samorządu terytorialnego dochody przewyższające koszty funkcjonowania daniny publicznej, dochody, które pozwalają jedynie na pokrycie kosztów związanych z jej poborem, czy też koszty przewyższające dochody z niej uzyskane. Połowa respondentów $50 \%$ wskazała, że opłata ta na ich terenie generuje określone dochody. $40 \%$ wskazało, że opłata generuje dochody, które jedynie pozwalają na pokrycie kosztów związanych z jej poborem, a 10 ankietowanych wskazało, że funkcjonowanie tej opłaty na ich terenie generuje koszty, które powstają wskutek egzekwowania należności od zobowiązanych. Jeżeli chodzi o kwoty planowanych dochodów z tytułu 
opłaty od posiadania psów w 2016 r. - to 35\% respondentów wskazało, że dochody $\mathrm{z}$ tego tytułu nie przekroczą 1 tysiąca złotych. U 30\% ankietowanych dochody z tytułu tej opłaty kształtować się będą w graniach od 1 tysiąca do 10 tysięcy złotych, a $25 \%$ ankietowanych wskazało, że dochody te nie przekroczą 20 tysięcy złotych. W pozostałej części gmin (10\%) dochody z tytułu opłaty od posiadania psów przekroczą 20 tysięcy złotych. Powyższe wyniki badań całkowicie potwierdzają kolejną hipotezę roboczą, że dochody uzyskane $\mathrm{z}$ opłaty od posiadania psów w większości gmin są znikome, w niektórych gminach dochody pozwalają jedynie na pokrycie kosztów związanych z jej poborem, a w nielicznych funkcjonowanie opłaty generuje koszty zamiast dochodów. Biorąc pod uwagę osiągane dochody z tytułu opłaty od posiadania psów oraz wpływy z innych podatków i opłat lokalnych (np. podatek od nieruchomości, podatek rolny, opłata targowa, uzdrowiskowa), można stwierdzić, że z fiskalnego punktu widzenia omawiana danina publiczna jest po prostu nieopłacalna.

Analiza kolejnego pytania zawartego w kwestionariuszu ankiety zanegowała następną hipotezę roboczą, w której założono, że większość podatników zobowiązanych do regulowania świadczenia pieniężnego uiszcza opłatę we wskazanym terminie. Odpowiedzi respondentów były bardzo rozbieżne. Zdaniem 30\% ankietowanych, na ich terenie zaledwie $10 \%$ wszystkich zobowiązanych wywiązało się $\mathrm{z}$ ciążącego na nich obowiązku zapłaty opłaty $\mathrm{w}$ terminie $\mathrm{w}$ roku 2015. 20\% ankietowanych było innego zdania i zaznaczyło, że z obowiązku wywiązują się prawie wszyscy podatnicy, mieszcząc się w przedziale od $91 \%$ do $100 \%$. Reszta gmin/miast wskazała różne granice przedziałów: $10 \%$ respondentów wskazywało przedziały od $11 \%$ do $20 \%$, od $21 \%$ do $30 \%$, od $61 \%$ do $70 \%, 71 \%$ do $80 \%$, a zaledwie $5 \%$ ankietowanych wskazało przedział mieszczący się w granicach od $51 \%$ do $60 \%$. Ponadto jeden z biorących udział podmiotów (5\%) nie udzielił odpowiedzi na to pytanie. Powyższe wyniki mogą prowadzić do wniosku, że gminy/miasta w województwie kujawskopomorskim mają trudności z efektywnym poborem tej opłaty i z mo- 
bilizowaniem społeczeństwa lokalnego do regulowania zobowiązań podatkowych względem samorządu gminy bez uprzedniego prowadzenia wobec nich czynności egzekucyjnych.

Nieuiszczenie opłaty od posiadania psów w terminie przez osoby zobowiązane winno skutkować wszczęciem odpowiedniego postępowania podatkowego zmierzającego do wyegzekwowania kwoty opłaty i zrealizowania obowiązku podatkowego ciążącego na podatniku, a wynikającego z przepisów prawa powszechnie obowiązującego. W pytaniu, które brzmiało: „Czy w Państwa gminie/mieście nieuiszczenie opłaty od posiadania psów przez osoby zobowiązane do jej zapłaty $\mathrm{w}$ terminie skutkuje wszczęciem postępowania podatkowego?”, większość respondentów (55\%) wskazała, że nie. Natomiast reszta ankietowanych (45\%) zaznaczyła odpowiedź twierdzącą. W związku z powyższym należy uznać, że koszty związane z przeprowadzeniem przez organ podatkowy postępowania podatkowego i czynności związanych ze ściągnięciem należności od dłużników podatkowych są na tyle wysokie, że przekroczą kwotę należności z tytułu opłaty od posiadania psów. Mając to na uwadze, jasnym jest, że samorządy rezygnują z egzekwowania należności z tytułu tych opłat.

Ostatnie pytanie zamieszczone $\mathrm{w}$ kwestionariuszu ankiety dotyczyło potencjalnej rezygnacji z opłaty od posiadania psów. Większość ankietowanych, tj. 55\% ogółu, stwierdziło, że nie posiada wiedzy na temat planowanej rezygnacji z przedmiotowej daniny publicznej. Pozostała część ankietowanych, tj. 45\%, wskazała, że w ich gminie/mieście nie przewiduje się zaniechania pobierania opłaty od posiadania psów. W ten sposób potwierdzono ostatnią hipotezę roboczą. Gminy województwa kujawsko-pomorskiego nie przewidują rezygnacji z poboru opłaty od posiadania psów, a powodem tego mogą być indywidualne pobudki każdego $\mathrm{z}$ ankietowanych podmiotów.

Podsumowując, przeprowadzone badanie na temat opłaty od posiadania psów w gminach województwa kujawsko-pomorskiego uznać należy za cenne źródło informacji. Analiza kwestionariuszy ankiety pozwoliła na poznanie funkcjonowania omawianej daniny 
publicznej w jednostkach samorządu terytorialnego. Badanie empiryczne wzbogaciło wiedzę w przedmiocie opłaty od posiadania psów występującej na terenie gmin województwa kujawsko-pomorskiego.

\section{Podsumowanie}

Obowiązująca od 1 stycznia 2008 r. opłata od posiadania psów ma charakter fakultatywny, a o jej wprowadzeniu decyduje rada gminy w drodze uchwały będącej aktem prawa miejscowego. Organ stanowiący gminy, podejmując decyzję o wprowadzeniu omawianej daniny publicznej na swój teren, musi uprzednio zweryfikować jej opłacalność ze względów finansowych, uwzględniając przy tym nie tylko cele fiskalne, ale także biorąc pod uwagę cele pozafiskalne ${ }^{41}$.

W praktyce opłaty lokalne, w tym opłata od posiadania psów, stanowią niski dochód publiczny, dlatego też gminy, decydując się na jej wprowadzenie, biorą pod uwagę funkcje administracyjnoporządkowe, wychowawcze oraz kompensacyjno-odszkodowawcze, a pozyskiwanie środków finansowych staje się dla nich sprawą drugorzędną ${ }^{42}$. Taki sam wniosek można także wyciągnąć z przeprowadzonego badania empirycznego. Jednakże nie powinno być tak, że fiskalna funkcja danin publicznych jest całkowicie zapomniana, gdyż to właśnie ona jest fundamentem ich istnienia i funkcjonowania. W sytuacji, gdy całkowicie zabraknie wskazanej funkcji, opłatę należy jak najszybciej usunąć z lokalnego prawa podatkowego, aby nie rodziła zbytecznych kosztów. Rozpatrując fiskalną funkcję daniny publicznej występującej w przepisach prawa podatkowego, trzeba mieć na względzie koszty poboru, pewność i gwarancję jej wpływu, a przede wszystkim szeroko rozumianą efektywność. Należy przyjąć, że organ gminy, który zobowiązany jest do stanowienia lokalnego prawa podatkowego, powinien uwzględnić związek między korzyścią płynącą

41 R. Dowgier, L. Etel, B. Pahl, M. Popławski, Podatki i opłaty lokalne. 601 pytań i odpowiedzi..., s. 659.

42 C. Kosikowski, J. Matuszewski, Opodatkowanie posiadania psów..., s. 164. 
z wprowadzenia opłaty ( $\mathrm{tj}$. osiągniętymi przychodami) a poniesionymi nakładami, które stanowią koszty jej uzyskania. Na podstawie wskazanej relacji organ gminy powinien zdecydować, czy opłata ta będzie przynosić fiskalne i pozafiskalne korzyści, czy też będzie zbędnym obciążeniem finansowym budżetu gminy ${ }^{43}$.

W gminach województwa kujawsko-pomorskiego, które uczestniczyły w badaniu, opłata od posiadania psów funkcjonuje od momentu wejścia w życie przepisów ustawy wprowadzających ją do systemu opłat lokalnych. Trudnością jest określenie podstawowej funkcji daniny publicznej, gdyż gminy nie miały jednoznacznego zdania. Dla części gmin priorytetową jest funkcja fiskalna, a dla innych górują nad nią funkcje pozafiskalne, czyli funkcja wychowawcza lub kompensacyjno-odszkodowawcza.

Dochody z opłaty od posiadania psów w większości gmin województwa kujawsko-pomorskiego nie przekraczają 10 tys. złotych, co prowadzi do wniosku, że w tych gminach funkcja fiskalna jest tą drugorzędną. W większości gmin opłata od posiadania psów generuje dochody, które są pewnie znikome, biorąc pod uwagę wpływy z innych podatków i opłat lokalnych. W niektórych gminach dochody te wystarczają jedynie na pokrycie kosztów związanych z poborem tej opłaty i kosztami postępowań podatkowych, ale są także takie gminy, gdzie opłata od posiadania psów generuje koszty i z punktu widzenia finansów samorządowych jest nieopłacalna. Gminy województwa kujawsko-pomorskiego mają problem $\mathrm{z}$ efektywnym poborem tej opłaty na swoim terenie, nie mogą zmobilizować mieszkańców do regulowania swoich zobowiązań, powinny więc wszczynać postępowania podatkowe zmierzające do wyegzekwowania należności podatkowych. Zadziwiającym jest fakt, iż w większości badanych gmin postępowania podatkowe $\mathrm{w}$ celu wyegzekwowania od zobowiązanych kwoty opłaty nie są wszczynane. Mimo wyżej wymienionych problemów gminy województwa kujawsko-pomorskiego nie zamie-

43 J. Politowicz, Funkcje i efektywność opłaty od posiadania psów..., s. 117-118. 
rzają w przyszłości rezygnować z poboru opłaty od posiadania psów na swoim obszarze.

Opłata od posiadania psów co pewien czas spotyka się z falą krytyki, zarówno ze strony społeczeństwa, jak i samorządów, które podejmując stosowną uchwałę, stają się zobowiązane do jej egzekwowania. Kluczowym problemem okazują się trudności z poborem opłaty, co $\mathrm{w}$ rezultacie prowadzi do rezygnacji gmin z daniny publicznej, która staje się po prostu nieefektywna. Kiedy w 2008 r. ustawodawca przekształcił podatek od posiadania psów w opłatę i tym samym nadał daninie fakultatywny charakter, wiele polskich miast zdecydowało się na niewprowadzenie opłaty, a gminy, które początkowo podjęły próby jej egzekwowania, stopniowo rezygnowały z jej funkcjonowania. Przykładem jest miasto Toruń, które w 2013 r. zrezygnowało z poboru opłaty od posiadania psów, gdyż koszty związane z prowadzeniem postępowań podatkowych i windykacyjnoegzekucyjnych przerosły wpływy z tej opłaty ${ }^{44}$. Z tego względu ustawodawca powinien się zastanowić, czy funkcjonowanie takiej opłaty w obecnym systemie prawnym jest naprawdę konieczne."

\section{Literatura:}

Borszowski P., Ustawa o podatkach i opłatach lokalnych. Komentarz, Wydawnictwo LexisNexis, Warszawa 2011.

Brzeziński B., Wprowadzenie do prawa podatkowego, Wydawnictwo TNOiK Dom Organizatora, Toruń 2008.

Ciąglewicz-Miśta A., Ciąglewicz N., Talik A., Podatki i opłaty lokalne. Komentarz. Projekty uchwał. Orzecznictwo, Wydawnictwo C.H.BECK, Warszawa 2011.

Dowgier R., Etel L., Pahl B., Popławski M., Podatki i opłaty lokalne. 601 pytań i odpowiedzi, Wydawnictwo Lex, Warszawa 2012.

Etel L., Dowgier R., Podatki i opłaty lokalne - czas na zmiany, Temida 2, Białystok 2013.

44 Tamże, s. 122. 
Kosikowski C., J. Matuszewski J., Opodatkowanie posiadania psów czyli płacz ze śmiechu wokół budy, Dom Wydawniczy ABC, Warszawa 2002.

Lasiński-Sulecki K., Morawski W., Komentarz do art. 18a ustawy o podatkach i opłatach lokalnych, [w:] Brzezicki T., Lasiński-Sulecki K., Morawski W., Wantoch-Rekowski J., Ustawa o podatkach i opłatach lokalnych. Komentarz, Wydawnictwo ODDK, Gdańsk 2013.

Łobocki M., Wprowadzenie do metodologii badań pedagogicznych, Oficyna Wydawnicza Impuls, Kraków 2007.

Michta D., Pankrac L., Podatki i opłaty lokalne. Komentarz. Orzecznictwo, Wydawnictwo Difin, Warszawa 2015.

Ofiarski Z., Ogólne prawo podatkowe. Zagadnienia materialnoprawne i proceduralne, Wydawnictwo LexisNexis, Warszawa 2010.

Politowicz J., Funkcje i efektywność opłaty od posiadania psów, [w:] Studenckie Prace Prawnicze, Administratywistyczne i Ekonomiczne 15, Wydawnictwo Uniwersytetu Wrocławskiego, Wrocław 2014. 